\title{
Dictynna
}

Dictynna

Revue de poétique latine

$6 \mid 2009$

Varia

\section{Irony and Aequabilitas : Horace, Satires 1.3}

\author{
Jerome Kemp
}

\section{OpenEdition}

\section{Journals}

Electronic version

URL: http://journals.openedition.org/dictynna/286

DOI: 10.4000/dictynna.286

ISSN: $1765-3142$

\section{Electronic reference}

Jerome Kemp, «Irony and Aequabilitas: Horace, Satires 1.3 », Dictynna [Online], 6| 2009, Online since 26 November 2010, connection on 10 September 2020. URL : http://journals.openedition.org/ dictynna/286 ; DOI : https://doi.org/10.4000/dictynna.286

This text was automatically generated on 10 September 2020 .

\section{(c) $(1) \Theta \Theta$}

Les contenus des la revue Dictynna sont mis à disposition selon les termes de la Licence Creative Commons Attribution - Pas d'Utilisation Commerciale - Pas de Modification 4.0 International. 


\title{
Irony and Aequabilitas : Horace, Satires $1.3^{1}$
}

\author{
Jerome Kemp
}

1 The third of Horace's opening 'diatribe' satires is the most systematic in terms of the consequentiality of its argument. ${ }^{2}$ The argument runs, logically enough, as follows: after an opening section on consistency (aequabilitas)/inconsistency (a theme which runs throughout the satire), Horace turns to consistency in the appraisal of one's own and one's friends' faults : there must be balance (aequabilitas) between the two, and this, practically, amounts to tolerance of friends' faults (25-95). From 76 tolerance and fairness in appraising friends' transgressions comes to include the judgment of crimes in society generally, and so introduces the section from 96 which deals with fairness (aequabilitas) in justice. ${ }^{3}$ The link between friendship and justice in Horace's argument reflects the pre-existing link between these subjects in Hellenistic thought, both in Stoicism and Epicureanism. And the end of this last section (124-142) also acts as a conclusion to the whole satire, where Horace upholds tolerance and fairness in friendship and justice against Stoic rigidity and extremism.

2 Although the underlying philosophical concept that runs through Satire 1.3, aequabilitas, is (as we will see) mainly identifiable with the Stoics, in comparison with the other so-called 'diatribe' satires, 1.3 is notable for its pronounced anti-Stoic stance. ${ }^{4}$ Horace's ironic handling of this Stoic tenet, and of philosophical material throughout the satire has, as yet, been somewhat overlooked. This discussion concerns the particular way in which Horace links aequabilitas with moderation, to promote his own, mainly Epicurean view of friendship and tolerance ; the uncovering of irony introduced by the theme of aequabilitas; and how Horace's use of philosophical material throughout enhances the sentiment and structure of his argument.

\section{Moderation and Consistency}

3 In so far as consistency (aequabilitas) is represented in 1.3, it is closely connected to moderation. There are in fact obvious connective similarities with the previous satire - 
1.2 , which explicitly concerned moderation in the conduct of one's sex life - in the opening section of 1.3 ; and indeed 1.3 generally has been seen as a continuation of the moderation theme which runs through this first triad of 'diatribe' satires. ${ }^{5}$ For example, in 1.2 (1-4) Horace uses the death of Tigellius Sardus to introduce the theme of moderation; in 1.3, from 3 to 19 Tigellius is described as someone who exemplified inconsistency. At 1.3.9 Horace defines Tigellius in the statement, nil aequale homini fuit illi, (reminiscent of nil medium est at 1.2.28) and then gives further examples of the man's absurd inconsistency, which is summed up, or rather parenthesised, by the further statement : nil fuit umquam sic impar sibi (19); and this can be compared with the similarly parenthetical 1.2.24/1.2.28, in the opening preamble on moderation/excess in 1.2. The fact that Horace deliberately treats consistency as similar to moderation in this opening section - bearing in mind 1.2 - is significant when we come to view his interrelation of philosophical ideas as the satire progresses.

Importantly, and, as we will see, somewhat ironically in a poem which is largely an attack on Stoic extremism, aequabilitas was particularly upheld by the Stoics (e.g. Cicero De officiis 1.90 and 111; De amicitia 65 and 92$) ;{ }^{6}$ its implication not merely being adherence to the same behaviour pattern, but to behaviour that is consistently rational and controlled and therefore reliable, and unaffected by vicissitude. On aequabilitas as a Stoic tenet Dyck remarks, with reference to De officiis (a work which represents, particularly in books 1 and 2, the views of the Stoic Panaetius) : "The Stoics held that all the sage's individual actions were correct and thus self-consistent (SVF 1. 52.27-29)... the self-consistency that Panaetius [in De officiis] recommends is thus modelled on that

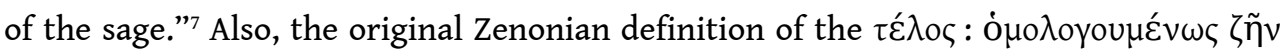

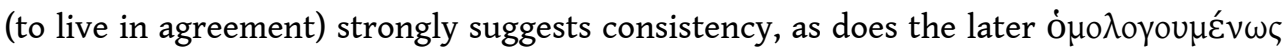

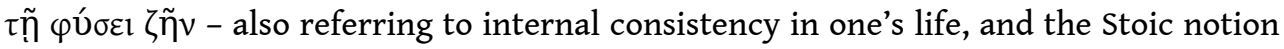

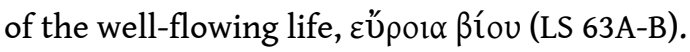

5 This self-consistency is very much a part of - in some respects practically indistinguishable from - moderation as part of temperate living ; and indeed Tigellius' inconsistencies up to 19 could also be regarded as excesses. For example, his tendency was to walk too quickly or too slowly $(9-11)^{8}$ or, at $15-17$ :

...............decies centena dedisses

huic parco, paucis contento, quinque diebus

nil erat in loculis.

Suppose you'd given a million to this frugal, easily satisfied individual : within five

days his pockets were sure to be empty. ${ }^{9}$

6 The connection with the Stoics - and in particular Panaetius - as being upholders of consistency is perhaps specifically suggested in Tigellius' inconsistent walking, since this is advised against in De officiis, at 1.131, where Cicero also refers to an excessively slow walk as looking like walking in a procession..$^{10}$ Indeed, the references to consistency given above from De officiis and De amicitia uphold this relationship between consistency and moderation : consistency being regarded in a practical - one could feasibly say, Panaetian ${ }^{11}$ - light, rather than as strict, inflexible adherence to particular modes of thought and behaviour, as would be expected in the Stoic sage, ${ }^{12}$ even if the Stoic sage is the ideal model for aequabilitas; indeed it is notable that the Panaetian De officiis 1 is where we find particular emphasis on the qualities of aequabilitas and constantia (consistency - in many contexts practically a synonym of aequabilitas). ${ }^{13}$ In this more practical context Horace would appear at first (1.3.1-24) to be supporting Panaetian Stoicism, but, as will become apparent, in 1.3 Horace takes on 
certain Stoic ideas discussed in the first book of De officiis, on consistency, reason (ratio), and the nature of human society and justice, and ironically uses them to attack Stoic extremism; and in so doing Horace aligns these virtues, in particular that of consistency, with Epicurean moderation. It must also be noted that both moderation the mean - and philia were central to Aristotelian ethics, ${ }^{14}$ and indeed the Aristotelian influence in the first three diatribe satires, which all deal with moderation and the mean to some extent, has been extensively covered, ${ }^{15}$ though here I focus on Horace's particular concentration on the more recognisably Stoic idea of consistency, and his consequent alignment of it with Epicurean moderation.

7 This alignment first becomes apparent when Horace moves on to discuss the subject of friendship at 25-53. In connection with the opening section on consistency, friendship is at first related to the inconsistent way in which men regard their friends' faults as disproportionately greater than their own. This inconsistency is also immoderate, and in highlighting this point Horace alludes to Lucretius, comparing this tendency with that of lovers who go to the other extreme, by indulging or even praising their beloved's shortcomings : $1.3 .38-40$ :

illuc praevertamur, amatorem quod amicae

turpia decipiunt caecum vitia, aut etiam ipsa haec

delectant, veluti Balbinum polypus Hagnae.

Let's turn our attention to this point, that the unsightly defects of a girlfriend escape her lover, in his blindness, or even actually delight him, as Hagna's wen did Balbinus.

8 The allusion is to DRN 4.1153-54, and it is also reminiscent of Sat. 1.2.90ff where Horace says that one should not be too fussy, on the one hand, nor be too blind to a woman's blemishes, on the other : the context in both involves the common sense of moderate detachment, and (in Sat. 1.2 in particular) ${ }^{16}$ of being satisfied with what is natural and necessary - according to the Epicurean view of moderation. ${ }^{17}$ Again, Horace also alludes to Lucretius at $43-49$, in describing the indulgent way a father would regard his son's faults :

at pater ut gnati, sic nos debemus amici

si quod sit vitium non fastidire: strabonem

appellat paetum pater, et pullum, male parvus

si cui filius est, ut abortivus fuit olim

Sisyphus... (43-47)

But, supposing a friend has some defect, we ought, just like a father with his son, not to feel disgust at it ; a father talks of a cross-eyed son as 'having a cast', and calls him 'wee chick' if he's woefully stunted like the midget Sisyphus...

Here Horace inverts Lucretius' list of the unctuous euphemisms which men attribute to their objects of desire at DRN 4.1160-69 (the comparison which Horace himself makes at $38-40)^{18}$ so as to support indulgence of faults rather than criticism. ${ }^{19}$ It may seem, in fact, that in suggesting that men indulge their friends' faults he is suggesting a somewhat immoderate course of action. However, the point is clearly that such indulgence is necessary to counter the more excessive tendency for men to overlook their own faults and exaggerate those of their friends : indeed in a sense Horace is here advising an application of aequabilitas, as balance, from a detached, moderate Epicurean perspective. $^{20}$

Balance is thus apparent in Horace's view that criticism of oneself should be consistent with criticism of one's friends : i.e. do not be over-critical of friends and under-critical of oneself. To counteract such a tendency and so restore aequabilitas Horace suggests 
indulgence of friends' faults. Horace's advocacy of balance is in this respect ironically tempered by his use of philosophical material. Horace is using an Epicurean source (Lucretius) to back up the notion of aequabilitas (most identifiable with the Stoics) through the Epicurean view of moderate detachment in order to save oneself from an excessive tendency (one based on false/empty opinion), while in turn implicitly attacking Stoic inflexibility and extremism; though the fact that the Stoics are the target of attack only becomes explicit from 96 with reference to the Stoic paradox, that all sins are equal.

11 The reasoning behind Horace's views on balance as tolerance can be seen to derive in other ways from Epicurean moderation. Between 68 and 75 he concludes that one should aim at fairness in regarding the faults of one's friends, which is suggestive of moderation. At 68, nam vitiis nemo sine nascitur; 'for no one is born without faults', seems to complement the Epicurean view expressed at 76-7, that faults cannot be eradicated :

denique, quatenus excidi penitus vitium irae

cetera item nequeunt stultis haerentia...

Again, since the fault of anger, and the others likewise which have a grip on the

victims of folly, can't be completely cut out....

As Lucretius DRN 3.307-322 : 310 :

nec radicitus evelli mala posse putandumst. ${ }^{21}$

The idea that one is born with faults and that they cannot be completely cut out suggests that for Horace one's own faults can only, realistically, be moderated. ${ }^{22}$

Horace's personal interpretation of ratio at 78 is another ironic jibe against the Stoics. ${ }^{23}$ Having made the point that one's faults cannot be completely removed, Horace suggests that ratio be used in implementing a sense of balance and fairness in judging misdemeanours; ratio - a quality particularly prized by the Stoics, and indeed by Cicero/ Panaetius in De officiis $1^{24}$ - is thus brought in to uphold the Epicurean view of moderation and fairness against Stoic extremism, and the view, (irrational, in Horace's opinion) at 96 , that all sins are equal.

So, in taking on the Stoic theme of consistency Horace aligns this with Epicurean moderation. And, as we will see, the ironic nature of this alignment of philosophical views, as well as his handling of the theme of consistency in other respects - in connection with friendship and tolerance, and in his subsequent use of philosophical sources - enhances this anti-Stoic position.

\section{Friendship : Consistency and Irony ; Tolerance and Criticism}

16 Horace's use of philosophical material, sometimes tinged with humour, and the unstable, casual nature of the satire form has led some to doubt whether the philosophical content in these satires should be taken seriously at all. ${ }^{25}$ However, this view could come close to regarding the humour (which still relies on a knowledge of the philosophical material : the satirist as shoddy moralist), and instability of the form as essentially contradicting what Horace regards as a particular characteristic of satire at 1.24-25 (quamquam ridentem dicere verum/ quid vetat) : ${ }^{26}$ the mixture of the serious and 
the humorous; indeed the underlying message, the truth (verum) is the important, moral purpose of Horatian satire. ${ }^{27}$

Certainly, to some extent we should be amused at the rather glib use of philosophical ideas to back up arguments involving how to conduct a (reasonably) contented sex life in 1.2 , for example, as Turpin notes $;^{28}$ but this does not mean that the satirist should be seen wholly as an incompetent moralist, even if Horace does present the satirist persona as at times rather careless in his formulation of argument, and rather easy with certain philosophical dicta. ${ }^{29}$ As we will see in Satire 1.3, the association of philosophical ideas, Horace's deliberate manipulation of them - even if sometimes so as to appear casual in the end serves to put forward an underlying philosophical position; if anything Horace's apparently casual use of ethical doctrine, his humour, in fact, demonstrates a satirist who is very much in control of the moral content in his work, and who uses the instability and humour of satire to strengthen particular philosophical arguments and the underlying moral seriousness of the poems. Because of the casual, almost apparently ramshackle nature of the satires, ethics is put in a recognisable, practical context, as it was in the street sermon diatribes, from which Horace draws. ${ }^{30}$ The irony in the moralising should not be regarded as undermining the moral content or making it practically worthless - if that were the case the irony would lose much of its effect. ${ }^{31}$

In Satire 1.3 Horace's position with regard to aequabilitas is ironic, and this is first implied in the introductory section: Horace's criticisms of the singer Tigellius (for his inconsistency) seem somewhat hypocritical set against his main argument from 25, which is tolerance of faults. ${ }^{32}$ More specifically, at 19-20 Horace imagines someone taking him to task about his criticisms of Tigellius : nunc aliquis dicat mihi "quid tu?

nullane habes vitia? "immo alia et fortasse minora.

At this point someone may say to me "What about you ? Haven't you any faults?'

Yes, but others, and perhaps they're smaller.

19 The irony here is that, after having said this Horace actually goes on to criticise men who regard their own faults as less serious than those of the friends they criticise (25-37). Indirectly Horace is thus criticising himself : Horace himself, it seems, is being somewhat inconsistent. Also, a source of irony lies in the subject matter - criticism of intolerance of others' faults (coupled with a disregard for one's own faults) - since this would appear to be an odd subject for a satirist to attack : a primary function of the satirist being to be critical of others' faults. In deftly, and ironically, showing how easy it is to fall prey to inconsistency, Horace actually exemplifies the seriousness - the truth - of the philosophical subject that runs through the poem : a good example of quamquam ridentem dicere verum/ quid vetat.

It may also be noted that Horace's satire is not particularly severe, and perhaps this pro-tolerance argument in 1.3 further suggests this. In Sat.1.4 too Horace maintains that his criticisms are reasonable : he is not writing satire simply to get cheap laughs (34-5), and will only criticise those who deserve it (65-70) - and this is further qualified by the fact that Horace rarely criticises contemporary individuals anyway. Indeed Horace's argument for tolerance - however touched by irony - taken together with his proclaimed stance as a satirist in 1.4 suggests that he intends his satire to be regarded not so much as aggressive, outspoken (and funny) criticism, but as something gentler his methods of persuasion, indeed, his irony, as more subtle. But Horace still sees 
himself as outspoken critic to some extent, as is shown by his wish to be seen in the literary tradition of Lucilius going back to Old Greek comedy.

In any case, Horace's stance in 1.3 in particular seems, ironically, somewhat inconsistent; and this is very much dependent on his use of philosophical dogma: he apparently recommends Stoic aequabilitas, while subtly presenting himself as a poor practitioner of this virtue, and this is largely why he goes on to recommend tolerance of faults (which, as we will see, can be regarded as essentially anti-Stoic): human beings are not perfect: nam vitiis nemo sine nascitur...68. Or, to put it another way, Horace's interpretation of aequabilitas leads him towards Epicurean moderation and tolerance, rather than to Stoic extremism and inflexibility. The irony in Horace's position as tolerant satirist, his inconsistency, and his general non-seriousness seem to act as a foil against the inflexible seriousness of the Stoic ideal of consistency, referred to explicitly from 96 to the end. So Horace's irony in fact serves to strengthen a philosophical position.

The thrust of the argument in favour of tolerance in friendship, indirectly introduced through the theme of aequabilitas, can be regarded as Epicurean. To begin with, it could be that such tolerance would in practice not be too demanding anyway, since perhaps for Horace friendships should only be formed with people of good character, as is suggested at Sat.1.6. 69-70 :

\section{purus et insons}

(ut me collaudem) si et vivo carus amicis...

If (to sing my own praises) I live a life which is pure and innocent and endears me to my friends...

This would in fact be in line with the view that one should choose one's friends after consideration, recommended by Epicurus (Sent. Vat. 28), ${ }^{33}$ as well as Laelius in Cicero's De amicitia (78). ${ }^{34}$ However, although this idea would also find favour with the Stoics, the Stoic view that only the wise can have friendships (Diog. Laert. 7.124, LS 67B= Diog. Laert. 7.32-3) would be too extreme :

Friendship, they declare, exists only between the wise and good, by reason of their likeness to one another... (Diog. Laert. 7.124).

Given that the Stoic qualification for wisdom was, practically speaking, unattainable, there would be no room for tolerance, as is implied in the polemical stance of Horace's argument from $96 .^{35}$ However, Fraisse $(1974: 348-373)$ has looked at the Stoic view of friendship in detail, making the point that the position that friendship only existed between the wise was an ideal and that moral progress towards such an ideal was also important. Also, it has been argued by Steinmetz $(1967: 191,199)$ that the Stoic Panaetius was a source for Cicero's De amicitia. ${ }^{36}$ Whether this is so or not, it seems likely that friendship could well have been treated in a more practical context by Panaetius, given his more practical approach to ethics generally (see note 12). ${ }^{37}$ But for Horace the extreme nature of the Stoic position that only the wise can enjoy friendship clearly calls for satirical criticism, and, indeed, the question of the possible Panaetian approach would still only be a later interpretation; the extreme nature of the Stoic position, as it stands, is unequivocal. ${ }^{38}$

But how Horace's views on tolerance in friendship can be regarded as specifically Epicurean needs further explanation; indeed it requires some discussion of the Epicurean view of friendship. For the Epicureans, friendship was an intrinsic virtue (Sent. Vat. 23) ${ }^{39}$ and living without friends a source of pain. This seems to originate in 
the idea that friendship promotes security (and a sense of security) ${ }^{40}$ through the mutual benefit of the parties involved: indeed it is said to originate from benefiting (Sent. Vat. 23). Thus one had to choose friendship to avoid a source of pain (and to avoid pain is to achieve pleasure). Such pain could, indeed, come both from the possible poverty, or injury (or fear of such), which could result from friendlessness, as well as from the lack of friendship as companionship, which is also a human need. Also, the Epicureans were aware that friendship can carry risks (Sent. Vat. 28). Clearly, if a friend were to meet with serious misfortune one should not abandon him (Diog. Laert. 10.120), but one should also remain in the friendship if the friend were committing some kind of injustice, provided the friend still behaved decently to oneself. ${ }^{41}$ Rist emphasises the Epicureans' regard for pistis, trust, in friendship (Sent. Vat. 34$){ }^{42}$ and that this was one of friendship's particularly pleasurable qualities : the existence of this trust, in spite of the risks, is what makes the friendship genuine and, indeed, pleasurable.

However, Mitsis and Annas ${ }^{43}$ regard the Epicurean position on friendship as incompatible with Epicurean hedonism..$^{44}$ For Annas the risks of friendship (in essence, the threat of pain) are at odds with the goal of pleasure. Mitsis is of the view that Epicurus in fact recognises an end in friendship completely separate from pleasure. ${ }^{45}$

In response to Mitsis, and largely compatible with Rist, O'Connor claims that Epicurean friendship is in accordance with a hedonistic ethical system. By O'Connor's reckoning, the kinds of risks in friendship that trouble Annas would barely exist in genuine Epicurean friendship (as Epicurus envisaged it). Epicurean friendship should be regarded rather as "friendly fellowship," 46 based on a mutual understanding of shared philosophical values: values which denounce greed, ambition, the fear of death, and even physical pain.

Horace's view of friendship is probably not quite the purist Epicurean kind described by O'Connor, although in the perhaps less ideal Epicurean friendship practised in $1^{\text {st }}$ Century B.C. Rome, a sort of fellowship of the wise is implied in the idea of there being an agreement - foedus - as mentioned by Torquatus in Cicero, Fin. 1.66ff : the friendship is on Epicurean terms. This idea of such an agreement - for which Epicurus felt no need because within an Epicurean community the implications of such a contract would already be understood - is also in keeping with the importance of pistis (trust), emphasised by Rist. This trust would be strengthened by such an agreement, and in turn strengthen the friendship against risks. This sense of loyalty, of pistis,seems also to be at the heart of Horace's views on the importance of tolerance in friendship in Satire 1.3, particularly in its diametric opposition to Stoic perfectionism and intolerance. It is certainly in keeping with Horace's readiness to forgive minor misdemeanours (83-95), and to indulge friends' faults on the basis that one is a friend, and that one is obliged to such loyalty, as at 33-35:

..........at est bonus, ut melior vir

non alius quisquam, at tibi amicus..

But he's a good man - there's none better - he's your friend... friendship are when this trust, this agreement in friendship, is brought into question :

.........quid faciam si furtum fecerit, aut si

prodiderit commissa fide sponsumve negarii? (94-95)

What am I to do if he commits theft, or betrays a trust or disowns his pledge? 
arly, this is why it is important to judge wisely before entering a friendship : that such an outcome does not arise. If one has trust based on an agreement between likeminded people, the risks of friendship are worth taking. ${ }^{47}$

However, Horace's essentially unequivocal position of favouring tolerance, which is most compatible with Epicureanism, is also not entirely without irony. At 63-67, when referring to his friendship with Maecenas, he depicts himself as being potentially subject to criticism :

simplicior quis et est, qualem me saepe libenter

obtulerim tibi, Maecenas, ut forte legentem

aut tacitum impellat quovis sermone molestus :

'communi sensu plane caret' inquimus. eheu,

quam temere in nosmet legem sancimus iniquam!

Or someone's rather direct, which is how I may have often blithely shown myself to you, Maecenas - so as to interrupt a person who is reading or quietly reflecting, and to pester him with some chatter or other : 'he's quite devoid of consideration' we pronounce. How blindly, alas, are we sanctioning an unkind precedent against ourselves!

Even here there is a sense in which although harsh criticism of such behaviour might be excessive, Horace still recognises that this behaviour is irritating. Certainly we can agree with Horace that there is nothing wrong with being rather direct (simplicior), but his explanation of what this entails perhaps leaves us less sure. In fact, the pest, or 'bore' in 1.9 is momentarily brought to mind; clearly Horace does not want to represent himself in that bad a light, but it would seem that his position is again tinged with irony. In fact sermone molestus may be a subtle, self-deprecating reference to the irritating nature of his own satire. ${ }^{48}$

Again, at $80 \mathrm{ff}$ Horace compares the possible extreme reaction of a master to a slave's minor transgression of helping himself to left-overs (which is to have him crucified), with someone over-reacting to the minor offence of a friend by hating and avoiding him ;9 at $90 \mathrm{ff}$ Horace gives a few examples of the kinds of trivial offences he means :

comminxit lectum potus mensave catillum

Evandri manibus tritum deiecit ; ob hanc rem,

aut positum ante mea quia pullum in parte catini

sustulit esuriens, minus hoc iucundus amicus

sit mihi?

He's wet the couch while drunk, or knocked a bowl worn thin by the hands of

Evander off the table: is this, or his having, in his hunger, helped himself to a chicken served up on my side of the dish, any reason why I should find him a less agreeable friend?

Although we should take Horace's point at face value in the run of the argument - that one should forgive trivial faults, indeed overlook them (85) - there is again some irony here in that the misdemeanours mentioned would certainly cause most hosts considerable annoyance : esuriens can certainly be seen as somewhat tongue-in-cheek..$^{50}$ Indeed, the behaviour here described takes place within the setting of the convivium, which is where we find uncouth behaviour elsewhere in the Satires (at 1.4.86ff and 2.8), and in these instances it is clearly presented as being objectionable. That said, the misdemeanours Horace describes in this passage (90ff) are presented either as accidental or at least not deliberately offensive, which is not the case in the behaviour of the boor-cum-satirist in 1.4 or Nasidienus in 2.8 . 
Horace's advocacy of tolerance of friends' faults, couched within the Stoic notion of aequabilitas, would surely oppose the Stoic view that only the virtuous can have friends which to all intents and purposes means no one at all, given that the truly wise or virtuous man for the Stoics is as rare as the Phoenix. ${ }^{51}$ As we have seen, Horace presents his position somewhat ironically, and this is reflected in his use of philosophical material. The use of a Lucretian rhetorical device at 1.3.44-54 does not of itself indicate that Horace is promoting an Epicurean view, but the explicitly anti-Stoic stance which follows from 96, the importance of trust, and thus tolerance, in Epicurean friendship - even though even here there is a dash of irony - as well as these Lucretian echoes and the Epicurean enthusiasm for friendship generally, show that the preceding argument on tolerance of friends' faults is Epicurean in spirit.

\section{The Link between Friendship and Justice}

An important aspect of the satire's progression is the link in Hellenistic thought between friendship and justice, and in the context of 1.3 one can perhaps regard Horace's awareness and use of this link as somewhat ironic - though its aim is unambiguous enough : to enhance an anti-Stoic position..$^{52}$ The satire's argument, after the introductory preamble, consists of three sections - on tolerance in friendship (25-95), fairness in justice (96-123), and a final section in which Horace concludes his views on tolerance and fairness in friendship and justice against Stoic inflexibility and intolerance. The discussion of tolerance of friends' faults effectively turns to one of justice at 96 and in so doing becomes explicitly anti-Stoic. This change is marked by the introduction of and consequent attack against the Stoic tenet that all transgressions are equal : quis paria esse fere placuit peccata (96). ${ }^{53}$ The progression from friendship to justice reflects the inter-relationship between these sociological subjects in Hellenistic thought, particularly in Stoicism, a point which has been overlooked by commentators.

For the Stoics friendship and justice were connected through oikeiosis $:^{54}$ the natural impulse of human beings to identify with other human beings. ${ }^{55}$ But perhaps more relevant to Horace's discussion of friendship and justice - particularly in connection with aequabilitas - is what Cicero/Panaetius says about justice and oikeiosis in De officiis 1. Panaetius, as Schofield notes, takes a somewhat different approach from the traditional orthodox Stoic view. ${ }^{56}$ Rather than justice being a result of oikeiosis, due to altruism - people's natural concern for others ${ }^{57}$ - Panaetius sees justice rather as a practical means by which one should protect the bonds in society which oikeiosis encourages, rather than as being a natural consequence of oikeiosis, as at Off.1.20:

sed iustitiae primum munus est, ut ne cui quis noceat nisi lacessitus iniuria.

of Justice, the first office is that no man should harm another unless he has been provoked by injustice. (tr. Atkins, Griffin 1991)

And this comes directly after the statement that kindness and generosity (clearly associated with friendship) are very much connected with justice $:^{58}$ thus the link between friendship and justice through oikeiosis is also clear in this Panaetian context. In fact, at Off. 1.12, 1.14, Cicero/Panaetius remarks that the important factor in arriving at justice in order to protect human society is ratio, which, as we have seen, is the very notion which Horace himself uses to oppose the Stoic view (connected with justice) that all faults are equal. Indeed Panaetius' stress on ratio in this respect is notable given Horace's use of the term at $78,{ }^{59}$ as is the fact that the quality of constantia is also 
referred to in this section (Off. 1.11-20,) i.e. at 1.12, 1.14, 1.17 : it seems likely that Horace had this discussion in De Officiis in mind when he came to write Sat. 1.3.

In fact, Panaetius' view of oikeiosis and its connection with justice - justice as a practical means to protect human society - is not dissimilar to Lucretius' sentiments on the practical reason for justice ${ }^{60}$ at $D R N 5.1019$ :

tunc et amicitiem coeperunt iungere aventes

finitimi inter se nec laedere nec violari.

Then also neighbours began to join friendship amongst themselves in their eagerness to neither harm nor suffer violence.

Or again for Epicurus (cf. RS 31) : the agreement between people not to harm each other - though the connection with friendship is also clear; indeed Long regards the above passage as describing the "imagined origins" of friendship. ${ }^{61}$

It would seem, in fact, that Horace has Lucretius, and in particular the passage quoted above (5. 926ff) in mind in the narrative from 96-124, in its didactic style, language and imagery. Denique (76), used as in Lucretius to begin a new section in the argument, ${ }^{62}$ foreshadows the Lucretian-style polemic to come from 96 , as does the aforementioned Lucretian idea that faults cannot be completely eradicated (76-77). At 109-111 the depiction of human beings, pre-justice, as snatching random love (Venerem incertam) echoes DRN 5.962; more ferarum (109) directly echoes Lucretius 5.932. ${ }^{63}$ Horace's description of the arrival of language as being the starting point for civilised society (104-6) may also derive from what Lucretius says at greater length at 5.1011-91. ${ }^{64} \mathrm{At}$ 107, the mention of Helen's adultery with Paris, which is linked with Horace's view of the possible violent repercussions from Venerem incertam, before the introduction of conventional law, may also be connected with Lucretius' depiction of Paris' love for Helen (which led to the Trojan War) at DRN 1.473-477.65 Although the use of the obscenity cunnus is clearly an obscene, satirical touch, ${ }^{66}$ it is also possible that cunnus is a pun on kunos (bitch) as rendered twice in the Iliad 6.344/356, where Helen is describing herself in such pejorative terms, as being the cause of war. Thus, this obscenity itself is linked to Homer, and in turn Lucretius. ${ }^{67}$

But the fact that Horace is also likely to be aware of the connection between friendship and justice in Stoic, and more particularly Panaetian (as dictated by ratio) oikeiosis here is perhaps partly indicated by the fact that he begins this passage as an explicit attack against a Stoic position, as well as by the way in which Horace himself ironically uses ratio - as if from an Epicurean perspective - to make this attack. Horace's critical response to the Stoic tenet that all sins are equal is that common sense is the best guide to justice, at $97-98$ :

\section{sensus moresque repugnant}

atque ipsa utilitas, iusti prope mater et aequi.

Instinct and tradition are ranged against them [i.e. the Stoics], and so is expediency,

which is in essence the mother of justice and fairness.

Indeed the Epicurean view is that it is natural for justice (essentially an agreement not to harm or be harmed : RS 31) to develop in order to meet the needs of a given society. ${ }^{68}$ The Stoics, on the other hand, regarded law as divine reason, ${ }^{69}$ and thus inflexible. Thismakes what Horace says at 113-114 appear to be a reaction against Stoicism, and an affirmation of Epicureanism : ${ }^{70}$

nec natura potest iusto secernere iniquum

dividit ut bona diversis, fugienda petendis ; 
nature cannot tell the unjust from the just as she marks off good things from bad, what is to be sought and what avoided. argument throughout the poem. That his position on friendship is anti-Stoic (i.e. before 96) is also suggested by the way in which the Stoic view that all faults are equal is initially brought in to conflict with his view on friendship : indeed this is effectively how Horace introduces the theme of justice. At any rate it would seem that a Stoic should regard a minor misdemeanour of a friend as tantamount to a serious offence, which is in keeping with the view that only the wise can enjoy true friendship and thus would not need to concern themselves with the business of forgiving or condemning a friend's misdemeanours anyway. Thus, given the demonstrably anti-Stoic stance of his argument, it seems likely that Horace's progression from friendship to justice shows an ironic awareness of the connection between friendship and justice found in Panaetius, through oikeiosis and the implementation of ratio, as rendered in off. 1.11-20.

The connection between friendship and justice through the common theme of tolerance is made explicit in the poem's conclusion (124b-142). In fact, the link between this last section and the preceding polemic is incidentally made at 123-4a (si tibi regnum/ permittant homines ; 'if men were to grant you regal power'). This is then picked up by an attack on the Stoic paradoxes that the wise man alone is rich, handsome and king. Then, at 137-142, Horace asserts that the Stoic wise man, because of his inflexible views on justice (and therefore friendship), and indeed his views of himself (as at 124b-133), will in fact be quite friendless, whereas Horace, in his relative Epicurean tolerance, will never be short of friends :

ne longum faciam : dum tu quadrante lavatum

rex ibis neque te quisquam stipator ineptum

praeter Crispinum sectabitur, et mihi dulces

ignoscent, si quid peccaro stultus, amici,

inque vicem illorum patiar delicta libenter,

privatusque magis vivam te rege beatus. (137-142)

To put it briefly : while you, king that you are, go to bathe for your farthing with no escort to attend you save the absurd Crispinus, my kindly friends will pardon me if I, in my folly, commit some transgression, and I in turn will gladly put up with their offences, and in my private station I shall live a happier life than Your Royal Highness.

\section{Conclusion}

Horace's ironic use of philosophical material - his interpretation of a Stoic tenet, which he apparently upholds from an Epicurean perspective in order to attack Stoic inflexibility - detracts from any sense of the poet taking himself too seriously, in antithesis to the Stoic sage ; and supports a pro-tolerance, pro-moderation Epicurean view. This Epicurean interpretation of aequabilitas is at odds with the extreme Stoic view : to the Stoics, Horace's application of aequabilitas would be illogical, since to them aequabilitas would in fact be compatible with intolerance : there is no room for human fallibility, for inconsistent behaviour.

But Horace wants to champion aequabilitas - as consistency, balance, moderation and tolerance - and in so doing he takes an aspect of Stoic doctrine to enrich his own essentially Epicurean views of moderation, tolerance and trust. Although this position would seem illogical to a Stoic, Horace shows how this Stoic view of aequabilitas is itself 
extreme and absurd. Through the marriage of Stoic aequabilitas and Epicurean tolerance and pistis, Horace steers a path which is most sympathetic to the Epicureans. In his discussion of tolerance there is still a touch of irony, though this does not detract from the unequivocal, Epicurean thrust of his argument. The explicit attack against Stoicism from 96 suggests that at a re-reading of the satire, his apparent upholding of the Stoic tenet of aequabilitas at the outset ought to be taken with a pinch of salt. And this anti-Stoicism, from 96 to the end, also suggests an ironic awareness of the Panaetian link between friendship and justice through oikeiosis, as dictated by ratio : again, in his argument, Horace sides with the link between friendship and justice as indicated in Lucretian, Epicurean terms, and ratio is used by Horace to undermine the unreasonable Stoic position that all sins are equal. Horace's anti-Stoic agenda is founded on an ironic awareness - and use - of Stoic thought, which is in turn interpreted from an Epicurean perspective. He uses the tenet of aequabilitas to lend irony to his own position, but also to define it as a distinctly personal, anti-Stoic one.

\section{BIBLIOGRAPHY}

Adams, J.N. 1982. The Latin Sexual Vocabulary. London.

Annas, J. 1993. The Morality of Happiness. Oxford.

Armstrong, D. 1964. "Horace, Satires 1.1-3 : A Structural Study," Arion 3.2 : 86-96.

Armstrong, D. 1989. Horace. New Haven.

E.M. Atkins, M.T. Griffin, eds. Cicero : On Duties (Cambridge 1991)

Brown, P.M. 1993. Horace, Satires I . Warminster.

Brown, R.D. 1987. Lucretius on Love and Sex : DRN IV. 1030-1247. Leiden.

Campbell, G. L. 2003. Lucretius on Creation and Evolution. Oxford.

Dufallo, B. 2000. "Satis/Satura : Reconsidering the Programmatic Intent of Horace's Satires 1.1," CW $93: 579-90$.

Du Quesnay, I.M Le M. 1984. "Horace and Meacenas : the Propaganda Value of Sermones I," in

T. Woodman and D. West (eds.), Poetry and Politics in the Age of Augustus. Cambridge : 19-58.

Dyck, A.R. 1996. Cicero : De Officiis. Ann Arbor.

Fowler, D. 2008, 'Lectures on Horace's Epistles,' PCPS : 80-114.

Fraenkel, E. 1957. Horace. Oxford.

Fraisse, J-C. 1974. Philia. Paris.

Freudenburg, K. 2001. Satires of Rome: Threatening poses from Lucilius to Juvenal. Cambridge.

Gill, C. 1994. "Peace of Mind and Being Yourself : Panaetius to Plutarch," ANRW 36.7 : 4599-4640.

P.G.W. Glare, ed. 1968-1982. The Oxford Latin Dictionary. Oxford. 
Gowers, E. 2003. “Fragments of Autobiography in Horace Satires 1.” ClAnt : 55-91.

Griffin, M. 1997. "Cicero and Matius on Friendship," in M. Griffin and J. Barnes (eds.), Philosophia TogataII. Oxford. 86-109.

Henderson, J. 2004. Morals and Villas in Seneca's Letters : Places to Dwell. Cambridge.

Hunter, R.L. 1985. “Horace on Friendship and Free Speech,” Hermes 113 : 480-490.

Inwood, B and Gerson, L.P. (eds.) 1994. The Epicurus Reader. Indianapolis.

Keane, C. 2006. Figuring Genre in Roman Satire. Oxford.

Kenney, E.J. 1971. Lucretius : De Rerum Natura, Book III. Cambridge.

Konstan, D. 1997. Friendship in the Classical World. Cambridge.

Lewis, C.T and Short, C. 1879. A Latin Dictionary: founded on Andrews' edition of Freund's Latin

Dictionary. Oxford.

Long, A.A. and Sedley, D.N. 1987. The Hellenistic Philosophers. Cambridge.

Long, A.A. 1986. "Pleasure and Social Utility - the virtues of being an Epicurean," in H. Flashar and O. Gigon (eds.), Aspects de la philosophie hellenistique. Geneva : 283-325.

Lyne, R.O.A.M. 1980. The Latin Love Poets (from Catullus to Horace). Oxford.

Macleod, C.W. 1979. “The Poetry of Ethics : Horace Epsitles 1,” JRS : 16-27.

Mayer, R.G. 1986. “Horace's Epistles 1 and Philosophy,” AJP : 55-73.

Mayer, R.G. 2005. "Sleeping with the enemy : Philosophy and Satire," in K. Freudenburg (ed.), The Cambridge Companion to Roman Satire. Cambridge. 146-159.

Mitsis, P. 1988. Epicurus' Ethical Theory. Ithaca.

Moles, J. 2003. “Diatribe," The Oxford Classical Dictionary. Oxford. 46-4.

Moles, J. 2007. "Philosophy and Ethics" in S. Harrison (ed.) The Cambridge Companion to Horace. Cambridge : 165-180.

Muecke, F. 1993. Horace,Satires II. Warminster.

O'Connor, D. 1989. “The invulnerable pleasures of Epicurean friendship,” GRBS $30: 165-186$.

Oliensis, E. 1998. "The Erotics of Patronage : Readings in Tibullus, Propertius, and Horace," in J.P. Hallett and M.B. Skinner M.B. (eds.). Roman Sexualities. Princeton : 151-171.

Oltramare, A. 1926. Les Origines de la Diatribe Romaine. Geneva.

Page, T.E. 1894. The Aeneid of Virgil, Books I-VI.London.

Powell, J.G.F. 1990. Cicero : Laelius de amicitia. Warminster.

Praechter, K. 1897. "Krantor and Ps. Archytas," Archiv für Geschichte der Philosophie 10 : 186-190, reprinted in 1973. Kleine Schriften. New York : 33-37.

Rist, J.M. 1980. "Epicurus on Friendship," CP 75 : pp 121-129.

Ruch, M. 1970. “Horace, Satires 1.3," EtCl 38 : 517-527.

Rudd, N. 1966. The Satires of Horace. Cambridge.

Schofield, M. 1995. "Two approaches to justice," in A. Laks and M. Schofield, Justice and Generosity. Cambridge. 191-212. 
Schofield, M. 1999. "Social and Political Thought," in K. Algra et. al. (eds.), The Cambridge History of Hellenistic Philosophy. Cambridge. 760-768.

Shackleton Bailey, D.R. 1982. AProfile of Horace. London.

Steinmetz, F-A. 1967. Die Fruendschaftslehre des Panaitios nach einer Analyse von Ciceros "Laelius de amicitia." Wiesbaden.

Turpin, W. 1998. “The Epicurean Parasite : Horace, Satires 1.1-3,” Ramus 27.2 : 127-40.

Wachsmuth, C and Hense, O. 1884. Stobaeus Johannes : Anthologium. Berlin.

\section{NOTES}

1. Particular thanks to Bob Sharples, Emily Gowers and Kirk Freudenburg for their helpful comments.

2. Cf. Brown 1993 : 115.

3. Uniformity of behaviour, equity, fairness and equability are listed as definitions of aequabilitas in $O L D$; law justice, impartiality (Lewis and Short).

4. Fraenkel $1957: 86$; Brown 1993 : 123. At 1.1.14, 120 and 1.2.134 Horace rather incidentally criticises the Stoics Fabius and Crispinus, but 1.3 comprises a more explicitly anti-Stoic argument. On the possible political implications of Horace's anti-Stoicism : Du Quesnay 1984 : 19-58.

5. Rudd 1966 : 1-35 ; Brown 1993 : 89-99 ; Armstrong 1964 : 86-96 ; 1989 ; 26-41.

6. Rudd $1966: 277-8$, n.46. On the Stoic tenor of much of De amicitia, see Powell $1990: 18-19$. As a commonplace in Greek (and, later, Roman) thought, the virtue of consistency is mentioned by Plato, quoting a proverb in Lysis 214c (Rudd 1966 : 27). The advisability of balance and harmony (more generally) is also found in the Republic 4.443d and Philebus 31c-32b, 64d-65d (Rudd 1966 : 276 n.34). Consistency of character is also promoted by Aristotle (e.g. NE 1166a10-1166b29) : Rudd $1966: 277-8$, n.45. With respect to Satire 1.3, however, it is important that the most obvious proponents of consistency were the Stoics (cf. Fraenkel $1957: 86 \mathrm{n} .4$ ) since from 96 to the end they comprise the target of Horace's criticism.

7. Dyck $1996: 281$.

8. cf. the stately pace of Aristotle's megalopsuchos (NE 1125a10-17), and Virgil Aeneid 1.46, where incedit suggests the dignity of Juno's movements (Page [1964, first ed. 1894] : 146) ; I owe these references to Aristotle and Virgil to R.W. Sharples. Also, cf. Seneca De ira 1.1.3, on the hurried step - citatus gradus - of the angry man.

9. Translations of Satires 1 are from Brown 1993, with adaptations.

10. ... ut pomparum ferculis similes esse videamur, aut in festinationibus suscipiamus nimias celeritates (Rudd, 1966, 28). Also, cf. Sallust Catiline 15.5: citus modo modo tardus incessus.

11. See below, p. 16 on De amicitia.

12. Horace saw that the Stoics' extreme position regarding the perfect kind of wisdom required to be a sage - or, indeed, to avoid being mad and a slave (as in the Stoic paradoxes satirised in 2.3 and 2.7) - was an easy target for satire.

However, it appears that by this time Stoic ethical theory had in fact tended towards a more practical approach (though it is still some time before Seneca). From Cicero's De officiis it is clear that Panaetius put more emphasis on the process of becoming wise, or as wise as one could be, rather than the goal of absolute wisdom itself. Clearly, the possible practical applications of Stoic idealism would still not deter critics of Stoicism from lampooning these apparently pompous statements. Indeed some Stoics certainly were austere and sanctimonious, and thus no doubt perceived as unreasonable, steadfastly standing by these ideals (as far as they could), such as 
Cato (Cicero: Murena 61-2, 74, Att. 1.18.7) and, one could suppose, the Stoics Horace himself satirises : Crispinus 1.1.120, 1.3.139, 1.4.14, 2.7.4 ; Fabius 1.1.14, 1.2.134), and in 2.3 Stertinius, and Crispinus (more indirectly), again, in 2.7.

13. Gill 1994 : 4608.

14. In books 8 and 9 of the Nicomachean Ethics; cf. below, notes 20, 22, 34 and 35.

15. e.g. Rudd 1966 : 1-35 ; Armstrong 1989 : 26-41, Brown 1993 : 89-90, 98, 101.

16. In Sat. 1.2 Horace's common sense advice on sexual behaviour involves a combination of the Aristotelian doctrine of the mean, as to kind of sexual partner, and the Epicurean view that one should be content with what is easily obtainable by nature, rather than pursuing empty desires : nonne, cupidinibus statuat natura modum quem,/ quid latura sibi quid sit dolitura negatum/ quaerere plus prodest et inane abscindere soldo? (111-113); also cf. 1.2.73-6. He recommends women that are available (freedwomen, meretrices) rather than the unavailable matrona - the pursuit of whom would be, in Epicurean terms, empty. (cf. below, n. 70).

17. Ep. Men. 127ff: "One must reckon that of desires some are natural, some groundless; and of the natural desires some are necessary and some merely natural ; and of the necessary, some are necessary for happiness and some for freeing the body from troubles and some for life itself." RS 29: "Of desires, some are natural and necessary, some natural and not necessary, and some neither natural nor necessary but occurring as a result of empty opinion." (tr. Inwood/Gerson 1994, with adaptations).

18. Indeed, Horace's explicit reference to this tendency in lovers, and his own comparison of father to son, reflects the wider connotation of amicitia generally, suggesting a similarity between these sorts of relationships ; cf. Catullus, who, in 75, seems in some way to have wrongly (to his own cost) regarded his relationship with Lesbia as a sort of amicitia: Lyne, 1980, 27-28. Also, on the relationship between amor and amicitia in Horace : Oliensis $1998: 151-171$.

19. cf. Plato, Republic 474d, Theocritus 10. 24-27 : R. Brown $1987: 129$.

20. As a factor in friendship and justice specifically, the idea of balance also has philosophical roots : most notably in Theophrastus and Aristotle. Theophrastus' views are put by Cicero in De amicitia 61 thus $(1.3: 25)$ :

cum vero amici utilitas nimio est amplior, honestatis autem nostrae in re non gravi levis iactura est, tunc, quod utile amico est, id prae illo, quod honestum nobis est, fit plenius, sicuti est magnum pondus aeris parva lamna auri pretiosus.

'But when the advantage of a friend is far larger and the sacrifice of our reputation in a matter of no importance is trifling, then that which is advantageous for a friend becomes more important in comparison with that which is honourable for us, just as a great weight of bronze is more valuable than a small liver of gold.' (tr. FHS \&G) : Attic Nights 1.3: 52 : Fortenbaugh, Huby, Sharples \& Gutas, vol. 2 1992, fr.534, 358.

This particular issue of conflicting interests seems to have certainly been developed by Theophrastus, having been brought up by Aristotle in the broader sense of weighing obligations of friendship against other obligations (NE 1160a2ff, 1165b22ff) : Griffin 1997 : 87. In NE 1158b20 Aristotle states that if the gap becomes too wide in respect of virtue and vice between friends, then such a friendship cannot persist. In all these instances some notion of proportion is important (as it is in Horace).

21. Brown $1993: 21$.

22. One may compare the Peripatetic notion, adopted by the Academics in opposition to the Stoics, that one should moderate one's emotions (metriopatheia) rather than aim to be devoid of emotion altogether (apatheia) : the Academics having adopted the doctrine of the mean from the Peripatetics (Cicero Tusc. 3. 22/ 4. 38ff). On the Academic Crantor's (335-275 B.C.) adoption of metriopatheia : Praechter, 1973 (first published 1897), 33-7.

23. Pseudo-acro commented that Horace's use of the terms ratio and fors at Sat. 1.1.3 were references to Stoicism and Epicureanism (Dufallo $2000: 81$ ). 
24. e.g., De officiis : $1.12,14,20,50,107$. See below : The Link between Friendship and Justice.

25. e.g., Freudenburg $2001: 15-23$; Turpin $1998: 27-40$; Dufallo (2000 : 79-90) notes the irony in Horace's sometimes paradoxical position as a literary artist in Satire 1.1 ; But he rightly takes the view that this encourages the reader to question the notion of moderation, of what is satis, and what is satire (Dufallo notes the punning link between satis, satur, and satura), rather than simply rendering the satire's moral and literary position as unserious. On the debate regarding philosophical content in Horace's works, see, for example, Macleod (1979), who regards the role of philosophy in the Epistles as significant; Mayer (1986), who plays down the philosophical content. See also Moles (2007), in particular the section on 'Further Reading.'

26. Indeed Dufallo $(2000 ; 584)$ notes that this is itself a satirical allusion to Lucretius - Horace's use of humour to make his ethical message more palatable being reminiscent of Lucretius' use of the poetic form to impart serious philosophy $(1.936 \mathrm{ff})$ - in that Horace apparently dismisses the allusion as a joke (1.1.27) : sed tamen amoto quaeramus seria ludo; but still, let's put jesting aside, and conduct a serious enquiry...'

27. Fowler (2008: 101) rightly maintains, in relation to Horace's changeable philosophical stance in the Epistles (e.g. Ep.1.1.16-19), that his portrayals and criticisms of these positions, again sometimes humorous, do not detract from the Epistles' philosophical seriousness; rather, we should see Horace's handling of, and enquiry into, different philosophical positions as Socratic, and further : "Horace's famous irony is certainly very Socratic, in a Kierkegaardian sort of way : the irony of the moral philosopher who jokes to be serious (e.g. end of Epistle 1)."

28. Turpin (1998) thinks we should regard the satirist in 1.1-3 as an incompetent Epicurean moralist, deliberately displayed as such by Horace. Turpin (128-9) draws attention to the fact that the Epicureans were in part perceived as sexual fanatics and thus 1.2, with its Epicurean terminology alongside the sexually obsessive nature of the narrator, can all be taken as deliberately somewhat absurd. To an extent it can be taken as such, and is intentionally funny e.g., the talking muto (1.2.68-72), the satirist's own probable adultery (126-134) - but Turpin does not consider the subtleties involved in Horace's use of philosophical material in terms of its bearing on the structure and argument of particular satires. Turpin misleadingly cites Epicurus Sent. Vat. 51 to stress his point about the perception of Epicureans as sexually permissive; he does not take account of the entire saying. Sent. Vat. 51 is in fact Metrodorus - not Epicurus - and the suggestion made here that one can indulge in sexual intercourse provided it does you no harm in fact, in Epicurean terms, should rather be regarded as generally advising against sexual intercourse (on the basis that it often will do you harm - as Satire 1.2 illustrates) : "so long as you do not break the laws or disturb proper and established conventions or distress any of your neighbours or ravage your body or squander the necessities of life, act upon your inclination in any way you like. Yet it is impossible not to be constrained by at least one of these. For sex is never advantageous, and one should be content if it does no harm." (tr. LS).

29. cf. Fowler on Epistles 1 (2008: 99-102), who argues that Horace as it were tries on different philosophies, just as he tries on different personae, to see how they fit; and so adopts a deliberately personal, ironic, but no less - in terms of its underlying purpose - serious approach to the main philosophical question of the Epistles : quid verum atque decens... (Ep. 1.1.11).

30. Whether or not the 'diatribe' was recognised as a literary genre at that time is irrelevant here : the important point is that there was a tradition of public street sermons, usually covering themes of popular philosophy (such as the folly of greed, adultery and ambition). The 'diatribe' was humorous, indeed satirical, employing the device of spoudaiogeloion ('joking in earnest') which is likely to have been derived from the Cynics (Oltramare 1926:15). From what has survived it seems that the diatribe was colloquial, avoiding systematic, logical argument and included devices such as fable, obscenity and parody (Brown 1993 ; 5 ; Kenney 1971 : 17-20). Thus a link between the diatribe and Roman satire, which shares all of these features, is clear. 
31. Hunter (1985) notes the ironic way in which Horace blurs friendship and flattery in Ep.1.18; but the effect of this blurring is to demonstrate the difficulty - in practical terms a real and serious one - in judging the appropriate way to behave in the company of a social superior.

32. Brown 1993 : 16. Indeed Shackleton Bailey (1982 : 23) notes that Horace, at 21-25, is criticising Maenius for doing to Naevius what Horace himself (1-19) does to Tigellius (though Tigellius is dead and not a friend of Horace's).

33. Sent. Vat. 28 : 'One must not approve of those who are excessively eager for friendship, nor those who are reluctant. But one must be willing to run some risks for the sake of friendship.'

34. cf. Theophrastus : 'judge before making friends, not make friends before judging them' as quoted by Plutarch De fraterno amore 482b, and referred to by Seneca Ep. 3.2. Aristotle advises judgment and caution in making friends (NE 8.3.1156b25ff).

35. Although Aristotle (NE 1165b23-36) and Cicero (Amic. 77) both state that if the corresponding levels of virtue between the two parties in a friendship become incompatible, then the friendship can be terminated, the Epicurean view was different: when forming a friendship one entered into a kind of contract (foedus : Cicero Fin. 1.69), and was thus obliged to stick by the friend unless the friend actually behaved unjustly to oneself and thus effectively broke the contract.

36. That Panaetius was a source for De amicitia is based on the grounds that there are similarities between the latter and De officiis, and on the further assumption, as Powell comments (1990: 18-19), that De officiis is entirely based on Panaetius: Powell sees no evidence for naming Panaetius as such an influence. But some influence, suggested by the link with De officiis, at least seems likely.

37. The fact that for the Stoics the achievement of wisdom was a process (Sen. Ep. 72.6) meant that they could follow the Peripatetic view of friendship as a possible means to selfimprovement: i.e., through the example of one's friends (NE 1169b28-1170a13, EE 1245b1-9, Cicero Deamicitia 83); this Peripatetic view is also compatible with the case of friendships

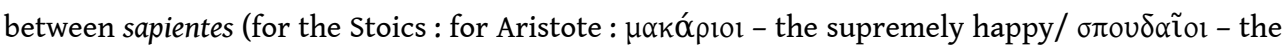
good), which would not so much involve self-improvement as the contemplation of one's friend's virtuous actions (and thus by comparison, one's own actions) ; and, again on a practical level, for the Stoics friendship was a preferred indifferent (Fin. 3.70) : Griffin $1997: 6$.

38. Konstan 1997 : 113-114.

39. 'All friendship is an intrinsic virtue, but it originates from benefiting.' (tr. LS).

40. i.e., that what promotes safety is a natural good : RS 6, 7 .

41. Rist (1980: 28) argues this point from Sent. Vat. 15 - following Bailey's text - where Epicurus says that one should value one's neighbours' characters if they are "decent" (epieikeis). Rist suggests that this implies approving of behaviour which is seemly as far as oneself might be affected by it ; it does not necessarily mean requiring that one's friends behave justly.

42. Sent. Vat. 34 : 'We do not need utility from our friends so much as we need confidence concerning that utility.'

43. Mitsis 1987 : 78-128; Annas 1993 : 43-4.

44. Cicero was critical of the Epicurean view of friendship as derived from utility and the enhancement of one's own pleasure, which he felt debased the idea of friendship (Fin. 1.66, 69, 2.80). But this may be partly due to a misunderstanding of what the Epicureans meant by utility and, indeed, pleasure.

45. This would be indicated by Sent. Vat. 23 (above): $\delta \imath^{\prime} \dot{\varepsilon} \alpha u \tau \eta ́ v ~ \alpha i \rho \varepsilon \tau \eta ́$; friendship is 'choiceworthy for its own sake' : Mitsis 1987: 104 - if we adopt the emended reading here of

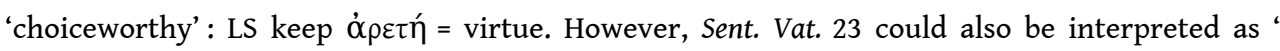
pleasant in itself : i.e., choiceworthy because it is intrinsically pleasant, rather than as something separate from pleasure. O'Connor (1989: 65-86) raises this possible interpretation although prefers a reading where there is no implied concessive in Sent. Vat. 23 : every friendship is choiceworthy for its own sake, and $(\delta \varepsilon)$ - rather than though - it takes its origin from benefiting : 
the second clause complements, rather than contrasts with, the first. Certainly, the idea of its being pleasant in itself seems most in keeping with Epicurus' eulogies of friendship in general, and complements the importance of trust in friendship : this too is pleasant in itself, irrespective of the actual, tangible benefits on which such trust originally rests.

46. O'Connor $1989: 176$.

47. Adopting a position of tolerance in line with Epicureanism, and setting this against Stoic extremism is not dissimilar to what Seneca does in Epistle 3 ; seneca draws from Epicurus to question the Stoic ideal of autarkeia, which he then supports, highlighting its practical application and its compatibility with friendship. Horace uses Stoic aequabilitas (in a practical context) to then attack Stoicism and to support Epicurean moderation. Again, on friendship in Epistle 3 Seneca appeals to the avoidance of extremes, to balance, and, at the end of the letter, to nature; Seneca also quotes Horace Satires 1 in order to strengthen his moral arguments (Ep. 86.13 = Sat. 1.2.27/ 4.92 ; Ep. 119.13-14 = Sat. 1.2.114-16 ; Ep. 120.20-21 = Sat. 1.3.11-17 (Henderson 2004 : 117-118). Notably, at Ep. 120.20-1, Seneca quotes Sat. 1.3 in order to conclude the letter on the wisdom of aequalitas.

48. Gowers $2003: 73$.

49. Although the general and important point is that one should not over-react to minor transgressions, it is possible that Horace, if only incidentally, is drawing attention to the fact that there is such an imbalance in the way in which people are judged for crimes simply because of their status. This seems possible, at least, bearing in mind Horace's background and the fact that his father had been a slave.

50. cf. Turpin $1998: 134$.

51. See above, n. 12.

52. Cf. Satire 1.1 where the connection between mempsimoiria (unhappiness with one's own lot, and envy of the lot of others) and greed appears to depend to some extent on the traditional inter-relation of these two subjects in popular philosophy (Fraenkel $1957: 92-4$ ).

53. Zeno, fr. 224, SVF i.54 ; Diog. Laert. 7.120. Ruch 1970 : 518-521, compartmentalises Horace's argument into 'moral' (29-75) and 'philosophique' (76ff), and thus differentiates between the more everyday observations and advice as regards friendship, and the more specifically philosophical question of grading faults and propounding a practical view of justice as to some extent dependent on present social circumstances.

54. The concept that one's natural concern for oneself spreads outwards, by degrees, to include (ultimately) all human beings is expressed by Hierocles in Stobaeus 4.617-673, 11 Wachsmuth = LS 57G. On the connection between oikeiosis and justice : Schofield, $1999: 760-768$.

55. Ibid. : Cicero De finibus 3.63. De officiis 1.55-6.

56. Schofield $1995:$ 191-212.

57. As at Off. 3.27, which is likely to represent the view of the second century BC Stoic, Antipater : Schofield $1995: 199-201$.

58. De tribus autem reliquis latissime patet ea ratio, qua societas hominum inter ipsos et vitae quasi communitas continentur: cuius partes duae, iustitia, in qua virtutis est splendor maximus, ex qua viri boni nominantur, et huic coniuncta beneficentia, quam eandem vel benignitatem vel liberalitatem appellari licet.

'Of the three that remain the most wide-reaching one is the reasoning (ratio) by which the fellowship of men with one another, and the life, are held together. There are two parts of this : justice, the most illustrious of the virtues, on account of which men are called good; and the beneficence connected with it, which may be called either kindness or liberality.' (tr. Atkins, Griffin 1991)

59. Panaetius stresses that reason (ratio) is what is distinctive about human society (Off. 1.11-12) : Schofield $1995: 203$.

60. Mitsis $1987: 106$. 
61. Long $1983: 310$.

62. Brown $1993: 121$.

63. More purely stylistic similarities include Horace's use at 1.3.111 (fateare necessest) of a subjunctive form commonly found in Lucretius (e.g. 1.399 esse in rebus inane tamen fateare necessest), vincet 115 = 'prove', cf. Lucretius 5.735 (Brown $1993: 124$ ) ; cf. Sat. 1.2.134.

64. Brown $1993: 124$.

65. Ibid.

66. e.g., Mayer 2005 : 249. Though in fact the obscenity cunnus itself is not found in satire anywhere else other than in Horace's Satires : Adams $1982: 81$.

67. On this passage as an analogy of the history of Satire - the progression from physical confrontation to verbal : Keane 2006:53; as an analogy of aspects of Horace's life : Gowers 2003 : 75. Campbell (2003: 218) notes that Horace's take on the emergence of civilisation from animalistic origins is more violent than Lucretius'. This would seem to be in keeping with the satirical context and Horace's references to violence in Satire 1.2.

68. For the Epicurean view of justice as conventional : RS 31, 32, 33 ; Lucretius DRN 5.1019-1027, 1143-1160 ; as mutable, depending on circumstances : RS 36, 37, 38 ; as a deterrent against wouldbe wrong-doers : RS 34, 35.

69. LS $67 \mathrm{R}, 67 \mathrm{~S}$.

70. cf. Sat. 1.2.75-6, ac non fugienda petendis/ immiscere, (Brown 1993 : 12). cf. also Sat.1.4.115-6: ' sapiens, vitatu quidque petitu/ sit melius...' Horace is differentiating, in an Epicurean context, between the empty and the solid, RS 29, what is naturally easy to obtain and what is naturally hard to obtain (ad Menoeceum 130), and thus what is to be sought and what avoided (ad Menoeceum 129ff, 132).

\section{ABSTRACTS}

In Satire 1.3 Horace upholds 'Stoic' aequabilitas, ironically aligning it with Epicurean moderation to attack Stoic inflexibility. His connection between friendship and justice shows an awareness of this link in Hellenistic thought. His ironic use of philosophical material serves a serious, antiStoic purpose (pace some recent scholarship).

\section{INDEX}

Mots-clés: Horace, Satire 1.3, irony, aequabilitas, friendship, tolerance, extremism, moderation, Epicureanism/Stoicism, justice, Lucretius, Panaetius, ratio, anti-Stoic position

\section{AUTHOR}

JEROME KEMP

jeromekemp@hotmail.com 